\title{
Biodiversity of segetal weed communities when chlorsulfuron-based weed control is being used on continuous winter wheat
}

\author{
Zbigniew Pawlonka*, Katarzyna Rymuza, Krzysztof Starczewski, Antoni Bombik
}

University of Natural Sciences and Humanities in Siedlce, Prusa 14, 08-110 Siedlce, Poland

Received: March 28, 2014

Accepted: August 11, 2014

\begin{abstract}
The purpose of the study was to determine the relationship between herbicide rate and weed community biodiversity in continuous wheat. A six-year field experiment was conducted to examine the effect of four chlorsulfuron rates in comparison with untreated (the control) plots, on the status and severity of weed infestation - in successive study years of cultivating winter wheat in monoculture. In addition, the following indices were calculated: Shannon-Wiener and Simpson's index of biodiversity, and Simpson's index of domination. A total of 36 weedy species were identified in the experimental plots. The richest segetal communities were established in the control plots. An application of herbicide reduced the biodiversity of the agrophytocensosis. A short-term monoculture did not impoverish the species richness of the weed community established in winter wheat. The average number of species in the community was significantly greater in the second study year. In the initial study years of monoculture, the biodiversity of the segetal community increased markedly compared with rotation-based cultivation. The calculated indices of biodiversity were not significantly affected by herbicide rate or monoculture but the indices confirmed the trends outlined by an analysis of the status and level of weed infestation.
\end{abstract}

Key words: biodiversity, domination, weeds, winter wheat

\section{Introduction}

The status and severity of weed infestation in a crop, determine the level of threat posed by the weeds. Infestation severity, defined as the total number or biomass of weeds per unit area is the simplest and most frequently used measure (Dobrzański 2009). An adverse effect is also conditioned by the number of weed species and their quantitative relationships, particularly dominating species. A weed community comprising several species may be and often is, more harmful than a community consisting of more than 10 species (Anyszka and Kohut 2011). As a result, the status of weed infestation, which is the number of weed species per unit area, has to be taken into account, too (Dobrzański 2009). Studies on weed infestation in crops, make more and more frequent use of ecological indices of species diversity and domination (Shannon 1948; Simpson 1949; Stupnicka-Rodzynkiewicz et al. 2004; Skrzyczyńska and Ługowska 2008; Rzymowska et al. 2013; Ługowska and Rzymowska 2014).

The objective of the present work was to determine the biodiversity of segetal weed communities establishing themselves in continuous winter wheat where weeds were controlled using different chlorsulfuron rates.

\section{Materials and Methods}

A field experiment was carried out in Wólka Leśna near Siedlce from 2004 to 2009 on grey brown podzolic soil (Luvisol). The trial was a randomised block arrangement with four replicates; the size of a plot was $2 \times 8 \mathrm{~m}$. Winter wheat cv. Korweta was cultivated in monoculture; it was sown at $250 \mathrm{~kg}$ grain per ha with the following rates of mineral fertilisers applied beforehand: $80 \mathrm{~kg} \mathrm{~N}, 70 \mathrm{~kg}$ $\mathrm{P}_{2} \mathrm{O}_{5}$, and $90 \mathrm{~kg} \mathrm{~K} 2 \mathrm{O}$ per ha. The study concerned the effect of the chlorsulfuron rate on the biodiversity of weed communities establishing in continuous winter wheat during each study year. The chlorsulfuron (applied as Glean $75 \mathrm{DF}$ ) rates were as follows:

1) the control - no chemical control;

2) $15 \mathrm{~g} / \mathrm{ha}$ applied in late autumn at the $\mathrm{BBCH} 17-19$ stage of wheat development;

3) $25 \mathrm{~g} / \mathrm{ha}$ applied in late autumn, $\mathrm{BBCH} 17-19$;

4) $25 \mathrm{~g} / \mathrm{ha}$ applied in late autumn, $\mathrm{BBCH} 17-19$, and $15 \mathrm{~g} /$ ha in early spring, BBCH 17-19 (40 g/ha in total);

5) $20 \mathrm{~g} /$ ha applied twice at 4-day intervals, BBCH 17-19, and once in early spring, BBCH 17-19 (60 g/ha in total).

The rates $40 \mathrm{~g} / \mathrm{ha}$ and $60 \mathrm{~g} / \mathrm{ha}$ were split into two and three applications, respectively. This was done so as not to destroy the crop plants. The maximum rates did not exceed $25 \mathrm{~g} / \mathrm{ha}$. 
In early June, weed infestation was determined using a quadrat. All individual weeds within the $0.5 \mathrm{~m}^{2}$ were counted in four places of a plot. Then, they were averaged and expressed on a $1 \mathrm{~m}^{2}$ basis.

The total number of species in all the experimental plots and in each study year was determined. What is more, the average number of weedy species per one plot was calculated for each herbicide rate and study year. The species composition of weed communities and number of plants of each species were used to assess the biodiversity by means of the following indices:

1) Shannon-Wiener index of species diversity $H^{\prime}$ (Shannon 1948):

$$
H^{\prime}=-\sum\left(p_{\mathrm{i}} \ln p_{\mathrm{i}}\right)
$$

2) Simpson's index of species diversity C (Simpson 1949):

$$
C=1-\sum p_{\mathrm{i}}^{2}
$$

3) Simpson's index of domination $D$ (Simpson 1949):

$$
D=\sum p_{\mathrm{i}}^{2}
$$

where $p_{\mathrm{i}}$ is the share of ith species in the sample.

All the indicators are widely used in studies of biocenosis diversity.

The values of indices were analysed using two-factorial variance analysis with the following main effects: chlorsulfuron rate and study year. Mean separation was obtained by Tukey's test at the significance level of $p \leq 0.05$ (Trętowski and Wójcik 1992). All the calculations were performed in Statistica 9.0.

\section{Results}

A total of 36 weedy species were found in all the study plots during the six-year study period. Individual segetal communities establishing at various rates of herbicide application included a total of 15 to 28 taxa. The average number of weedy species ranged from 3.3 to 6.5 . The highest number of weedy species was in the non-treated control and the plots where a reduced herbicide rate was applied. As the herbicide rate was increased, less and less weedy species were found. Statistically, the poorest weed communities established where there was an increased chlorsulfuron rate. The total number of weeds ranged from 55.2 (at the highest chlorsulfuron rate) to 83.7 plants per $\mathrm{m}^{2}$ (at the lowest rate) (Table 1 ).

The length of monoculture had a much less pronounced effect on the species number of the agrophytocenoses. An average number of weedy species was only significantly higher in the second study year. Weed infestation was significantly higher in the sixth study year; amounting to 137.4 plants $/ \mathrm{m}^{2}$ (Table 2).

The calculated indices of biodiversity demonstrated that biodiversity of the weed community was affected by the chlorsulfuron rate. The communities which established in non-treated plots had the highest values of biodiversity indices and the lowest index of domination
$\left(H^{\prime}=2.4 ; C=0.86 ; D=0.14\right)$. As chlorsulfuron rates were increased, the biodiversity of the communities declined and was the lowest in the plots where the per-hectare rate of $40 \mathrm{~g}$ chlorsulfuron was applied $\left(H^{\prime}=1.53 ; C=0.61\right.$; $D=0.39$ ). The index of domination was the lowest in these plots, too. The highest chlorsulfuron rate, $60 \mathrm{~g} / \mathrm{ha}$, increased biodiversity $\left(H^{\prime}=1.74 ; C=0.73\right)$ but reduced domination $(D=0.27)$. However, the relationships were not statistically significant (Fig. 1).

In the initial study years, the biodiversity of the segetal community in continuous winter wheat markedly increased compared with rotation-based cultivation. The richest community established itself in the second study year $\left(H^{\prime}=2.46 ; C=0.86 ; D=0.12\right)$. The agrophytocenosis was substantially impoverished in the last study year $\left(H^{\prime}=\right.$ $=0.78 ; C=0.36 ; D=0.64$ ) but the relationships were not statistically significant (Fig. 2).

\section{Discussion}

The study results indicated that winter wheat agrophytocenosis was substantially impoverished due to chemical weed control. In non-treated plots, the segetal community consisted of 6.5 species, on average. As chlorsulfuron rates increased, the floristic richness gradually decreased till a level of 3.3 species was reached. The total number of species dropped from 28 to 15 . The findings of other authors are different. In the study by Rychcik (2006), herbicides applied in continuous maize reduced the number of species in the community from 26 to 20 . Also, Jędruszczak and Antoszek (2004) as well as Adamiak et al. (2011) have reported that herbicides had a negative impact on weed communities in winter wheat. By contrast, Stupnicka-Rodzynkiewicz et al. (2004), who examined communities in winter wheat and spring barley, have claimed that an application of herbicides reduces the number of weeds but it does not affect their diversity. In turn, Jastrzębska et al. (2007) did not notice any effect of weed control type on the biodiversity of weed communities in faba bean.

Normally, herbicides markedly reduce the number of weeds (Stupnicka-Rodzynkiewicz et al. 2004; Rychcik 2006). In the study discussed here, statistically significant differences were found between the lowest and the highest rate of chlorsulfuron.

The effect of cultivation in monoculture on the total number of weedy species in the community and the total number of weeds, was much less pronounced. The community was significantly richer only in the second study year. Weed infestation was the lowest in the third study year and the highest in the sixth year. Kwiatkowski et al. (2004) and Rychcik (2006) and observed a significant increase in weed infestation in continuous maize and spring barley compared with rotation-based cultivation.

The indices of biodiversity also confirmed the abovementioned findings. An application of herbicide reduced the biodiversity of the agrophytocenosis and increased the index of domination. It is interesting to note, that the weed community established after spraying with the highest chlorsulfuron rate (60 g/ha), had higher indices of biodiversity and lower species domination than the 
Table 1. Species composition and number of weeds $\left(\mathrm{plants} / \mathrm{m}^{2}\right.$ ) in winter wheat, depending on the chlorsulfuron rate (means for 2004-2009). Species nomenclature follows Mirek et al. (2002)

\begin{tabular}{|c|c|c|c|c|c|c|}
\hline \multirow{2}{*}{ Weed species } & \multicolumn{6}{|c|}{ Chlorsulfuron rate $[\mathrm{g} / \mathrm{ha}]$} \\
\hline & the control & 15 & 25 & 40 & 60 & mean \\
\hline Elymus repens (L.) Gould & 14.2 & 33.1 & 29.7 & 35.7 & 25.9 & 27.72 \\
\hline Gnaphalium uliginosum L. & 3.8 & 9.5 & 14.4 & 5.4 & 5.3 & 7.68 \\
\hline Apera spica-venti (L.) P. Beauv. & 17.8 & 6.2 & 2.5 & 3.5 & 4.4 & 6.88 \\
\hline Viola arvensis Murray & 4.7 & 9.8 & 5.4 & 3.1 & 6.0 & 5.80 \\
\hline Juncus bufonius L. & 2.9 & 0.8 & 5.8 & 2.9 & 5.8 & 3.64 \\
\hline Echinochloa crus-galli (L.) P. Beauv. & 1.0 & 1.6 & 2.6 & 2.5 & 4.7 & 2.48 \\
\hline Matricaria maritima subsp. inodora (L.) Dostal & 5.9 & 3.3 & 1.3 & 0.3 & 0.0 & 2.16 \\
\hline Plantago intermedia Gilib. & 1.0 & 3.0 & 4.3 & 1.4 & 0.0 & 1.94 \\
\hline Cirsium arvense (L.) Scop. & 3.7 & 2.7 & 1.3 & 0.0 & 0.0 & 1.54 \\
\hline Fallopia convolvulus (L.) A. Lowe & 3.2 & 2.0 & 0.8 & 0.2 & 0.2 & 1.28 \\
\hline Plantago major L. S. Str. & 0.7 & 1.0 & 1.8 & 0.7 & 0.2 & 0.88 \\
\hline Centaurea cyanus L. & 2.2 & 0.6 & 0.6 & 0.1 & 0.3 & 0.76 \\
\hline Bromus secalinus L. & 0.0 & 0.9 & 0.5 & 1.2 & 1.2 & 0.76 \\
\hline Galeopsis tetrahit L. & 0.0 & 2.8 & 0.7 & 0.0 & 0.0 & 0.70 \\
\hline Polygonum aviculare $\mathrm{L}$. & 1.5 & 0.6 & 0.5 & 0.2 & 0.0 & 0.56 \\
\hline Stellaria media (L.) Vill. & 2.6 & 0.0 & 0.0 & 0.0 & 0.0 & 0.52 \\
\hline Artemisia vulgaris $\mathrm{L}$. & 0.9 & 0.9 & 0.2 & 0.2 & 0.4 & 0.52 \\
\hline Pоа аппиа L. & 1.2 & 1.2 & 0.0 & 0.0 & 0.2 & 0.52 \\
\hline Chenopodium album $\mathrm{L}$. & 1.7 & 0.7 & 0.0 & 0.0 & 0.0 & 0.48 \\
\hline Taraxacum officinale F. H. Wigg. & 0.2 & 0.5 & 0.3 & 1.1 & 0.3 & 0.48 \\
\hline Sonchus asper (L.) Hill & 0.0 & 1.5 & 0.0 & 0.1 & 0.0 & 0.32 \\
\hline Conyza canadensis (L.) Cronquist & 0.1 & 0.1 & 0.5 & 0.2 & 0.0 & 0.18 \\
\hline $\begin{array}{l}\text { Polygonum lapathifolium L. subsp. } \\
\text { lapathifolium }\end{array}$ & 0.7 & 0.2 & 0.0 & 0.0 & 0.0 & 0.18 \\
\hline Anchusa arvensis (L.) M. Bieb. & 0.6 & 0.2 & 0.0 & 0.0 & 0.0 & 0.16 \\
\hline Setaria pumila (Poir.) Roem \& Schult. & 0.2 & 0.2 & 0.2 & 0.0 & 0.0 & 0.12 \\
\hline Galinsoga parviflora Cav. & 0.0 & 0.1 & 0.2 & 0.0 & 0.1 & 0.08 \\
\hline Veronica arvensis L. & 0.0 & 0.0 & 0.2 & 0.0 & 0.2 & 0.08 \\
\hline Vicia tetrasperma (L.) Schreb. & 0.3 & 0.0 & 0.0 & 0.0 & 0.0 & 0.06 \\
\hline Trifolium repens subsp. repens L. & 0.2 & 0.0 & 0.1 & 0.0 & 0.0 & 0.06 \\
\hline Galium aparine $\mathrm{L}$. & 0.1 & 0.0 & 0.0 & 0.1 & 0.0 & 0.04 \\
\hline Lithospermum arvense $\mathrm{L}$. & 0.2 & 0.0 & 0.0 & 0.0 & 0.0 & 0.04 \\
\hline Senecio vulgaris $\mathrm{L}$. & 0.0 & 0.0 & 0.2 & 0.0 & 0.0 & 0.04 \\
\hline Trifolium pratense $\mathrm{L}$. & 0.0 & 0.1 & 0.0 & 0.0 & 0.0 & 0.02 \\
\hline Equisetum arvense $\mathrm{L}$. & 0.1 & 0.0 & 0.0 & 0.0 & 0.0 & 0.02 \\
\hline Setaria viridis (L.) P. Beauv. & 0.0 & 0.1 & 0.0 & 0.0 & 0.0 & 0.02 \\
\hline Rumex crispus L. & 0.1 & 0.0 & 0.0 & 0.0 & 0.0 & 0.02 \\
\hline Total number of weeds & $71.8 \mathrm{ab}$ & $83.7 \mathrm{~b}$ & $74.1 \mathrm{ab}$ & $58.9 \mathrm{ab}$ & $55.2 \mathrm{a}$ & 68.74 \\
\hline Total number of species & 28.0 & 27.0 & 23.0 & 18.0 & 15.0 & 36.0 \\
\hline Mean number of species & $6.5 \mathrm{c}$ & $6.5 \mathrm{c}$ & $5.1 \mathrm{~b}$ & $3.8 \mathrm{a}$ & $3.3 \mathrm{a}$ & 5.04 \\
\hline
\end{tabular}

Means in rows followed by the same letters do not differ significantly $(\mathrm{p} \leq 0.05)$ 
Table 2. Species composition and number of weeds (plants $/ \mathrm{m}^{2}$ ) in winter wheat in the consecutive study years. Species nomenclature follows Mirek et al. (2002)

\begin{tabular}{|c|c|c|c|c|c|c|}
\hline \multirow{2}{*}{ Weed species } & \multicolumn{6}{|c|}{ Years } \\
\hline & 2004 & 2005 & 2006 & 2007 & 2008 & 2009 \\
\hline Elymus repens (L.) Gould & 0.3 & 8.2 & 7.8 & 13.6 & 28.4 & 108.0 \\
\hline Gnaphalium uliginosum L. & 15.7 & 6.7 & 0.1 & 11.7 & 11.7 & 0.4 \\
\hline Apera spica-venti (L.) P. Beauv. & 1.2 & 5.7 & 1.5 & 8.2 & 6.0 & 18.8 \\
\hline Viola arvensis Murray & 4.6 & 17.7 & 2.6 & 8.3 & 1.6 & 0.0 \\
\hline Juncus bufonius L. & 15.5 & 0.0 & 0.0 & 4.0 & 2.5 & 0.0 \\
\hline Echinochloa crus-galli (L.) P. Beauv. & 0.0 & 3.8 & 4.0 & 1.4 & 5.7 & 0.0 \\
\hline Matricaria maritima subsp. inodora (L.) Dostal & 2.5 & 4.9 & 1.0 & 3.3 & 0.6 & 0.8 \\
\hline Plantago intermedia Gilib. & 5.6 & 0.0 & 0.0 & 6.0 & 0.1 & 0.0 \\
\hline Cirsium arvense (L.) Scop. & 0.0 & 0.3 & 0.7 & 0.8 & 4.0 & 3.6 \\
\hline Fallopia convolvulus (L.) A. Lowe & 1.5 & 2.5 & 1.1 & 0.8 & 1.4 & 0.4 \\
\hline Plantago major L. S. Str. & 0.0 & 2.7 & 0.6 & 0.0 & 1.7 & 0.0 \\
\hline Centaurea cyanus L. & 0.5 & 1.6 & 0.5 & 0.5 & 1.2 & 0.2 \\
\hline Bromus secalinus L. & 0.0 & 0.0 & 0.1 & 0.0 & 0.0 & 4.4 \\
\hline Galeopsis tetrahit L. & 0.7 & 1.4 & 0.0 & 0.6 & 1.6 & 0.0 \\
\hline Polygonum aviculare $\mathrm{L}$. & 0.4 & 0.0 & 2.7 & 0.0 & 0.2 & 0.0 \\
\hline Stellaria media (L.) Vill. & 0.0 & 3.0 & 0.0 & 0.1 & 0.0 & 0.0 \\
\hline Artemisia vulgaris L. & 0.0 & 1.5 & 0.7 & 0.5 & 0.4 & 0.2 \\
\hline Poа аппиа L. & 0.3 & 3.0 & 0.0 & 0.0 & 0.0 & 0.0 \\
\hline Chenopodium album $\mathrm{L}$. & 0.2 & 1.3 & 1.4 & 0.0 & 0.0 & 0.0 \\
\hline Taraxacum officinale F. H. Wigg. & 2.2 & 0.1 & 0.0 & 0.0 & 0.3 & 0.4 \\
\hline Sonchus asper (L.) Hill & 0.1 & 0.1 & 0.0 & 0.5 & 1.1 & 0.2 \\
\hline Conyza canadensis (L.) Cronquist & 0.1 & 0.6 & 0.0 & 0.2 & 0.1 & 0.0 \\
\hline Polygonum lapathifolium L. subsp. lapathifolium & 0.0 & 0.0 & 1.1 & 0.0 & 0.0 & 0.0 \\
\hline Anchusa arvensis (L.) M. Bieb. & 0.0 & 0.9 & 0.0 & 0.0 & 0.0 & 0.0 \\
\hline Setaria pumila (Poir.) Roem \& Schult. & 0.0 & 0.0 & 0.5 & 0.1 & 0.1 & 0.0 \\
\hline Galinsoga parviflora Cav. & 0.1 & 0.0 & 0.0 & 0.0 & 0.3 & 0.0 \\
\hline Veronica arvensis L. & 0.6 & 0.3 & 0.0 & 0.0 & 0.0 & 0.0 \\
\hline Vicia tetrasperma (L.) Schreb. & 0.3 & 0.0 & 0.0 & 0.1 & 0.0 & 0.0 \\
\hline Trifolium repens subsp. repens L. & 0.4 & 0.0 & 0.0 & 0.0 & 0.0 & 0.0 \\
\hline Galium aparine $\mathrm{L}$. & 0.0 & 0.0 & 0.1 & 0.1 & 0.0 & 0.0 \\
\hline Lithospermum arvense $\mathrm{L}$. & 0.0 & 0.0 & 0.3 & 0.0 & 0.0 & 0.0 \\
\hline Senecio vulgaris L. & 0.0 & 0.0 & 0.0 & 0.2 & 0.0 & 0.0 \\
\hline Trifolium pratense $\mathrm{L}$. & 0.0 & 0.1 & 0.0 & 0.0 & 0.0 & 0.0 \\
\hline Equisetum arvense $\mathrm{L}$. & 0.0 & 0.0 & 0.0 & 0.1 & 0.0 & 0.0 \\
\hline Setaria viridis (L.) P. Beauv. & 0.0 & 0.0 & 0.0 & 0.1 & 0.0 & 0.0 \\
\hline Rumex crispus L. & 0.0 & 0.0 & 0.0 & 0.0 & 0.1 & 0.0 \\
\hline Total number of weeds & $52.8 \mathrm{ab}$ & $66.4 \mathrm{~b}$ & $26.8 \mathrm{a}$ & $61.2 \mathrm{~b}$ & $69.1 \mathrm{~b}$ & $137.4 \mathrm{c}$ \\
\hline Total number of species & 20.0 & 21.0 & 18.0 & 22.0 & 21.0 & 11.0 \\
\hline Mean number of species & $4.7 \mathrm{a}$ & $7.0 \mathrm{~b}$ & $4.2 \mathrm{a}$ & $5.5 \mathrm{a}$ & $5.1 \mathrm{a}$ & $3.6 \mathrm{a}$ \\
\hline
\end{tabular}

Means in rows followed by the same letters do not differ significantly $(\mathrm{p} \leq 0.05)$ 


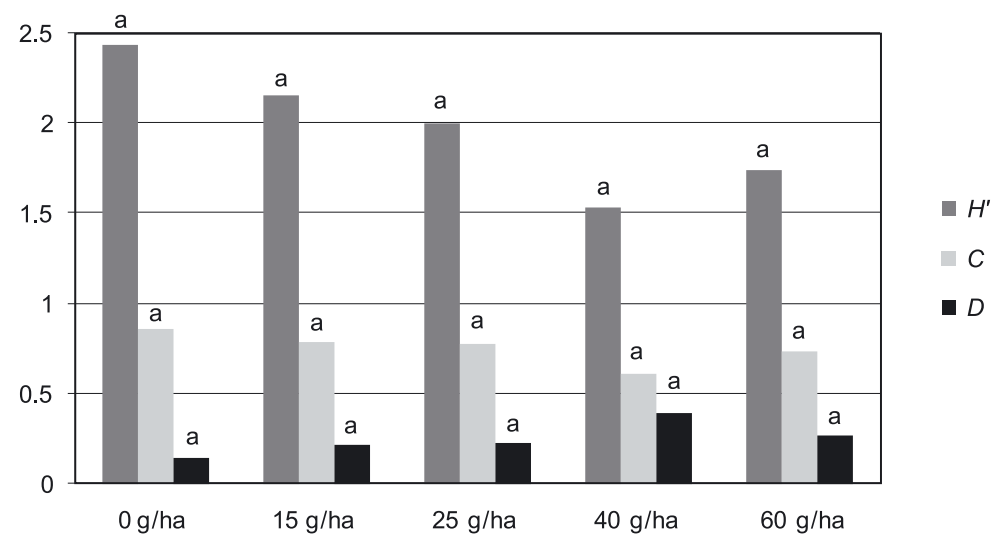

Means followed by the same letters do not differ significantly $(\mathrm{p} \leq 0.05)$

Fig. 1. Shannon-Wiener index of species diversity $\left(H^{\prime}\right)$, Simpson's index of species diversity $(C)$, and Simpson's index of domination $(D)$ in winter wheat depending on the chlorsulfuron rate (averaged over the years 2004-2009)

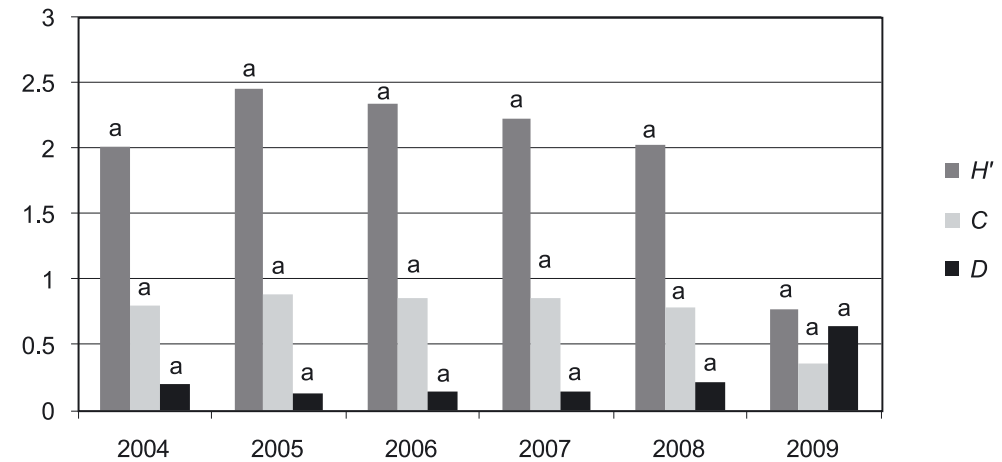

Means followed by the same letters do not differ significantly $(\mathrm{p} \leq 0.05)$

Fig. 2. Shannon-Wiener index of species diversity $\left(H^{\prime}\right)$, Simpson's index of species diversity $(C)$, and Simpson's index of domination $(D)$ in winter wheat in consecutive study years (averaged over the chlorsulfuron rates)

community established after an application of the lower herbicide rate $(40 \mathrm{~g} / \mathrm{ha})$, despite a lower total number of species.

Values of indices of biodiversity in consecutive study years indicated that short-term monoculture (several years long) does not impoverish an agrophytocenosis. On the contrary, such cultivation increases its biodiversity and reduces species domination. Other authors have reported different findings. According to StupnickiaRodzynkiewicz et al. (2004), an effect of crop rotation on weedy species diversity is insignificant, whereas Jędruszczak and Antoszek (2004) have claimed that the longer the monoculture, the higher the index of domination and the lower the index of overall diversity.

The similarity of biological indices, number of species, and number of weeds in the community, emphasised by Anyszka and Kohut (2011), was high but not complete in the present study. The indices of biodiversity did not depend significantly on an application of herbicide and monoculture but largely confirmed the trends following from analysis of the status and severity of weed infestation.

\section{References}

Adamiak E., Adamiak J., Przybylski R. 2011. Znaczenie płodozmianu $\mathrm{w}$ regulacji zachwaszczenia zbóż ozimych. [Significance of crop rotation on the regulation weed infestation in winter cereales]. Prog. Plant Prot./Post. Ochr. Roślin 51 (2): 817-821.

Anyszka Z., Kohut M. 2011. Bioróżnorodność zbiorowisk chwastów segetalnych w uprawach wybranych gatunków warzyw. [Biodiversity of segetal weed communities in cultivations of selected vegetable crops]. Prog. Plant Prot./ Post. Ochr. Roślin 51 (3): 1219-1223.

Dobrzański A. 2009. Biologiczne i agrotechniczne aspekty regulowania zachwaszczenia. [Biological and agronomic aspects regulate weed]. http://www.agengpol.pl/LinkClick.aspx?fileticket=kJB9Gx vZm4M\%3D\&tabid=144 [Accessed: January 21, 2014].

Jastrzębska M., Bogucka B., Hruszka M. 2007. Następstwo roślin i proekologiczne sposoby regulacji zachwaszczenia a bioróżnorodność chwastów w bobiku. [Crop sequence and environment-friendly weed control methods versus weed biodiversity in faba bean fields]. Acta Agrophys. 10 (2): 357-371. 
Jędruszczak M., Antoszek R. 2004. Sposoby uprawy roli a bioróżnorodność zbiorowisk chwastów w monokulturze pszenicy ozimej. [Tillage systems and biodiversity of weed communities in winter wheat monoculture]. Acta Sci. Pol., Agricultura 3 (2): 47-59.

Kwiatkowski C., Wesołowski M., Stępień A. 2004. Bioróżnorodność chwastów w trzech odmianach jęczmienia jarego uprawianych w siedmioletniej monokulturze i zmianowaniu. [Biodiversity of weeds in three cultivars of spring barley grown in seven-year monoculture and crop rotation]. Acta Sci. Pol., Agricultura 3 (2): 109-117.

Ługowska M., Rzymowska Z. 2014. The effect of the application of the exact and approximate methods on values of selected ecological indices. Acta Agrobot. 67 (1): 39-46. DOI: 10.5586/aa.2014.0.

Mirek Z., Piękoś-Mirkowa H., Zając A., Zając M. 2002. Flowering plants and pteridophytes of Poland - a checklist. p. 1-188. In: "Biodiversity of Poland" (Z. Mirek, ed.). W. Szafer Institute of Botany, Polish Academy of Sciences, Kraków, 442 pp.

Rychcik B. 2006. Wpływ herbicydów i następstwa roślin na zachwaszczenie kukurydzy (Zea mays L.). [Effect of herbicides and crop sequence on weed infestation of maize (Zea mays L.)]. Prog. Plant Prot./Post. Ochr. Roślin 46 (2): 170-173.
Rzymowska Z., Ługowska M., Skrzyczyńska J. 2013. Species diversity of segetal communities in tuber crops and in winter and spring cereals. Acta Agrobot. 66 (3): 95-102. DOI: 10.5586/aa.2013.043.

Shannon C.E. 1948. A mathematical theory of communication. Bell System Technical J. 27: 379-423, 623-656.

Simpson E.H. 1949. Measurement of diversity. Nature 163: 688.

Skrzyczyńska J., Ługowska M. 2008. Dominacja gatunków i bioróżnorodność zbiorowisk agrocenoz ziemniaka Doliny Środkowej Wisły. [Species domination and biodiversity in weed communities of agrocenoses of the middle Vistula valley]. Zesz. Prob. Post. Nauk Rol. 530: 105-115.

Stupnicka-Rodzynkiewicz E., Stępnik K., Lepiarczyk A. 2004. Wpływ zmianowania, sposobu uprawy roli i herbicydów na bioróżnorodność zbiorowisk chwastów. [Effect of the crop rotation, tillage method and herbicides on the biodiversity of weed communities]. Acta Sci. Pol., Agricultura 3 (2): 235-245.

Trętowski J., Wójcik A.R., 1992. Metodyka doświadczeń rolniczych. [Methodology of agricultural experiments]. Wyższa Szkoła Rolniczo-Pedagogiczna, Siedlce, 538 pp. 